\title{
Integrated Best Management for Tuta Absoluta (Lepidoptera:Gelechiidae) Infesting Tomato Plants in Egypt
}

\author{
Saad, A.S.A. ${ }^{1}$, E. H. M. Tayeb1, Lila M. Abdel-Nabi ${ }^{2}$ and Hoda G. A. I. Attia ${ }^{2}$ \\ 1- Plant Protection Dept., Faculty of Agric. (Saba Basha), Alexandria Univ., Egypt \\ 2- Agric. Res. Center, El-Sabahia, Alexandria, Egypt
}

\begin{abstract}
Tomato plants were sprayed three times (at 15 days intervals) with different evaluated insecticidal treatments during two following growing seasons of 2012 and 2013 in an approach to achieve efficient control against the tomato leafminer (borer) Tuta absoluta. During the first season of 2102, the treatment of emamectin benzoate+Kz oil was more effective and reduced the number of larvae and increased their reduction percentages up to $40.9 \%$ as compared with the other performed treatments of the $1^{\text {st }}$ spray. After the $2^{\text {nd }}$ spray, the treatment of chlorantraniliprole+Mineral oil was the most potent one and recorded the highest general mean of reduction over 10 days of inspection (89.9\%) followed by chlorantraniliprole (alone) $(81.3 \%)$. Furthermore, post- $3^{\text {rd }}$ spray the mixture of metaflumizone $+\mathrm{Kz}$ oil ${ }^{\Theta}$ was proved to be the utmost superior treatment and achieved complete reduction (100\%) all over the adopted inspection periods ( 5,7 , and 10 days). The same trend of results was gained during the second season of 2013. The addition of the mineral oil $\left(\mathrm{Kz}\right.$ oil $\left.{ }^{\circledR}\right)$ increased the efficiency of the evaluated insecticides :emamectin benzoate, chlorantraniliprole and metaflumizone; therefore it is recommended to admix mineral oil with each of these effective evaluated insecticides. So, they could be used in IPM programs for achieving potent control of Tuta absoluta.
\end{abstract}

Keywords: Tomato plants, the tomato leafminer Tuta absoluta, insecticidal treatments, mineral oil, reduction percentage

\section{INTRODUCTION}

Tomato crop (Solanum lycopersicum L.) is affected by many insects and fungal diseases, among which, the insects Trialeurodes vaporariorum and Tuta absoluta, and the fungi Alternaria spp. and Botrytis cinerea are of great incidence (Bue et al., 2012). The tomato leafminer (tomato borer) Tuta absoluta Povolny, native to western South America, is an extremely devastating insectpest in planted tomato crops in most of South America, Europe and Africa (North of the Sahel). It causes yield losses up to $100 \%$ and decreases fruit quality in open field and greenhouse crops if control methods are not applied (Bueno et al., 2012). This insect- pest has spread rapidly throughout the Mediterranean area, and has also reached the countries of northern Europe. In 2009, Tuta absoluta has been found in the UK and the Netherlands travelling on Spanish tomato imports (Miniermotte, 2010). It was also first observed in the year of 2010 damaging the tomato plants in different countries; Egypt (Mohammed, 2010), Israel (Seplyarsky et al., 2010), Turkey (Unlu, 2012 and KIc, 2010), Montenegro, Italy (Hrncic and Radonjic, 2011), Iran (Baniameri and Cheraghian, 2012), Russia (Izhevsky et al., 2011), Greece (Roditakis et al., 2010) and Khartoum State, Sudan (Mohamed et al., 2012). The pest occurs throughout the entire growing cycle of tomatoes both for fresh market and processing, and larval feeding can cause losses up to 100\% (Desneux et al., 2010)

Because of its characteristic biology and behavior, T. absoluta is a challenging insect-pest to control. T. absoluta has been controlled with synthetic insecticides. Organophosphates and pyrethroids were used during the 1970's 
and 1980's. New products (abamectin, spinosad, tebufonzide and chlorfenpyr) were introduced in the 1990's (Lietti et al., 2005). At least 12 classes of insecticides are being used for controlling T. absoluta (IRAC, 2009a and 2009b). Control failures had been noted with Organophosphates and pyrethroids in South America (Salazar and Araya, 2001) prompted research on the resistance status of $T$. absoluta (Lietti et al., 2005; Siqueira et al., 2000a, 2000b). However, newer classes of insecticides provided good control of this pest (IRAC, 2009a). Indoxacarb, spinosad, imidacloprid, deltamethrin, and Bacillus thuringiensis var. kurstaki were applied for the control of larval infestations in Spain (FERA, 2009; Russell, 2009). Chlorpyrifos and pyrethrins were used in Italy (Garzia et al., 2009). Abamectin, indoxacarb, spinosad, imidacloprid, thiacloprid, lufenuron, and Bacillus thuringiensis $(B t)$ were recommended for infestation outbreaks in Malta (Mallia, 2009). In Brazil, abamectin, cartap, chlorfenapyr, phenthoate, methamidophos, spinosad, and indoxacarb were recommended for use in the South, Southeastern, and Savannah tomato-growing regions, while chlorfenapyr, phenthoate, and spinosad were recommended for use in the Northeastern region (IRAC, 2007). In Argentina, Bt and triflumuron were recommended for the control of $T$. absoluta larvae as part of an IPM program that also included parasitoids (Riquelme, 2006).

In Egypt, T. absoluta is newly reported and until now there are two registered insecticides (Dipel- $2 X^{\circledR}$ and Proclaim ${ }^{\circledR}$ ) for controlling this insect. However, in Egypt there are going on evaluation of some insecticides under registration and few studies describing the efficiency of some insecticides for the control of T. absoluta (Derbalah el al., 2012; Shalaby et al., 2012; Hanafy and El-Sayed 2013; Soliman et al., 2013; Ramadan, 2014). Therefore, certain insecticidal treatments compatible with IPM programmes were evaluated for their efficiency against $T$. absoluta infesting tomato plants in Egypt.

\section{MATERIALS AND METHODS}

\section{Field experiment}

Field trials were carried out in El-Sabahia Agricultural Research Center during June of 2012 (summer season) and the farm of Faculty of Agricultural (Saba Basha), Alex. Univ. at Abis $10^{\text {th }}$ village, Alexandria Governorate during March of 2013 (winter season). The planted area was of approximately 3-5 Kerat. The selected experimental areas were divided into longitudinal blocks separated by buffer paths of $1 \mathrm{~m}^{2}$ wide between every plot $\left(180 \mathrm{~m}^{2}\right)$ to prevent insecticides drift. Transplanted tomato seedlings (Variety Malika) were grown all over the different blocks. The recommended agricultural practices were followed during both seasons according to recommendations of the Egyptian Ministry of Agriculture.

The presence of $T$. absoluta was confirmed by inspecting the occurring symptoms of morphological changes in tested plants of the collected specimens from the field. 
Two sticky pheromone traps (Pherodis ${ }^{\circledR}$ ) all over the growing season were used and they were replaced within that plot treated with detergent (Masrol ${ }^{\circledR}$ ). The used trap with the pheromone (yellow) (1 lure) is specific for $T$. absoluta and it is produced by Koppert Biological System.

\section{Insecticidal treatments}

In both seasons of 2012 and 2013, each block of planted tomato contained three replicates / treatment. The plants of untreated check (control) were chosen to be a little far away from those treated plants to avoid any contamination or interference of spray drift.

Four different insecticidal treatments were evaluated; each treatment was applied at three consequent sprays $\left(1^{\text {st }}, 2^{\text {nd }}\right.$ and $\left.3^{\text {rd }}\right)$ in addition to a $5^{\text {th }}$ treatment which has been used as untreated check (control) . The adopted $1^{\text {st }}$ treatment of first spray included trap+detergent, emamectin benzoate, emamectin benzoate+Kz-oil and Engeo ${ }^{\circledR}$ (thiamethoxam + lambda-cyhalothrin). The treatment of second $\left(2^{\text {nd }}\right)$ spray included trap+detergent, chlorantraniliprole $\left(\right.$ Coragen ${ }^{\circledR}$ ), chlorantraniliprole+Kz-oil and chlorfenapy+ spinotoram. The third $\left(3^{\text {rd }}\right)$ spray also included each of trap+detergent, metaflumizone, metaflumizone+Kz-oil and methomyl+ indoxacarb. All sprayed plants in the performed treatments were compared with the untreated check plants (Table 1).

In the second season of 2013, the aforementioned four insecticidal treatments (plus the control one) in each consequent $1^{\text {st }}, 2^{\text {nd }}$ and 3rd sprays were identically carried out as that done in the first season of 2012. The insecticidal applications were done when the plants were at the age of 2 months using a Knapsack sprayer (20 liters), at the rate of 200 liters / fed at 15 day intervals.

Table (1): The rate, trade and common names of the evaluated pesticides

\begin{tabular}{|c|c|c|}
\hline Trade name & Common name & $\begin{array}{l}\text { Rate/Fed. } \\
(\mathrm{ml})\end{array}$ \\
\hline Alferdy ${ }^{\circledR}$ & Metaflumizone & 200 \\
\hline Avaunt $^{(\circledast)}$ & Indoxacarb & 50 \\
\hline Coragen $20^{(\Theta} \% S C$ & Chlorantraniliprole & 60 \\
\hline Masrole $\left.{ }^{(}\right)$ & Detergent & 1000 \\
\hline Engeo $^{\circledR}$ & $\begin{array}{l}14.1 \% \text { thiamethoxam }+10.6 \% \\
\text { lambda-cyhalothrin }\end{array}$ & 100 \\
\hline $\mathrm{Kz}$ oil ${ }^{\circledR}$ & Mineral oil & 1000 \\
\hline Lannate $^{(\circledast)}$ & Methomyl & $300 \mathrm{~g}$ \\
\hline Proclaim $^{\circledR} 5 \%$ EC & Emamectin benzoate & $120 \mathrm{~g}$ \\
\hline Radiant ${ }^{\circledR} 12 \%$ SC & Spinotoram & $100^{\circ}$ \\
\hline Chalenger $^{(B)}$ & Chlorfenapy & 100 \\
\hline
\end{tabular}

\section{Sampling technique and inspection of the Tuta absoluta}

The infestation rate was recorded after 5,7 and 10 days post- spraying taking into account the mean number of larvae / 8sampled plants /replicate in 
each treatment compared with control. Percentages of infestation reduction were also calculated. The estimated infestation rate in treatments was determined pre- and after 5, 7 and 10 days from insecticidal applications and the percentages of infestation reduction were calculated using Henderson and Tilton (1955) equation as follows:

$$
\text { Reduction } \%=1-\left[\frac{\text { A }}{B} \times \frac{C}{D}\right] \times 100 \text { where, }
$$

A: number of larvae in treatment after treatment.

$B$ : number of larvae in treatment before treatment.

C: number of larvae in the check before treatment.

D: number of larvae in the check after treatment.

\section{Statistical analysis}

Data of the present study were subjected to the analysis of variance ANOVA using " $F$ " Test following the randomized complete block design (RCBD). The least significant differences (L.S.D) at the 0.05 probabilty level were determined according to computer program (COSTAT software, 1988) and Steel and Torrie (1981) to compare the average mean numbers of the different treatments and control.

\section{RESULTS AND DISCUSSION}

During the first season of 2012, four insecticidal treatments were evaluated against the tomato leafminer (tomato borer) Tuta absoluta compared with the untreated check after the first spray. The residual effect of each of these treatments on the mean number of detected larvae on tomato plants and calculated reduction percentages are presented in Table 2. It could be seen that the mean numbers of larvae are going to be decreased till the $10^{\text {th }}$ day posttreatment. Meanwhile, the calculated percentage of reduction of each treatment was found to have, merely, the same trend. Considering the general mean (\%) of reduction caused by the application of the different performed insecticdes, it is noticed that the treatment of emamectin benzoate $+\mathrm{Kz}$ oil was effective for reducing the number of larvae and increased their reduction percentages up to $40.9 \%$, followed by the treatment of trap+ Detergent that gave a reduction percentage of 35.6. The addition of $\mathrm{Kz}$ oil to emamectin benzoate increased its efficacy; showed the highest reduction percentage of inspected larvae as compared with emamectin benzoate alone which recorded the least reduction percentage of 23.6 (Table 2).

The second spray included three different insecticidal treatments with the previously used treatment of trap+ Detergent and the untreated check (Table 3). Before the application of the evaluated treatments of the second spray, it was noticed that the number of the detected larvae increased. Nevertheless, the three tested treatments (chlorantraniliprole, chlorantraniliprole+Mineral oil and chlorfenapyr+spinetoram) were so effective in reducing the number of inspected larvae and increasing the calculated reduction percentages. The results revealed that the treatment of chlorantraniliprole+Mineral oil was the most potent one; recording the highest general mean of reduction of $89.9 \%$ over 10 
days of inspection, followed by the treatment of chlorantraniliprole alone $(81.3 \%)$. Herein, the addition of the mineral oil increased the efficiency of chlorantraniliprole when they were admixed and presented a promising efficient chemical mixture for controlling Tuta absoluta; that mixture would be included within IPM programs. The effective treatment of the mixture of chlorantraniliprole+ spinetoram $(78.1 \%)$ was less potentthan that mixture of chlorantraniliprole+Mineral oil in reducing the larval occurrence. A possibility for reducing pesticide applications in tomato fields is the use of integrating management methods such as proper plant spacing within the row (Guedes et al., 1994), and use of mineral oil in the insecticide mixtures (Guedes et al., 1995) as well as improved production systems (Picanco et al., 1995).

The effect of certain applied treatmentsin the $3^{\text {rd }}$ spray against the tomato leafminer, Tuta absoluta in 2012 season is shown in Table 4. It could be seen again that the addition of the mineral oil to an insecticide is increasing its toxicological activity. The mixture of metaflumizone+Kz oil was proved to be the superior achieving complete reduction (100\%) all over the inspection periods post-spraying. The addition of the mineral oil to metaflumizone was found to double its activity. These results are in agreements with those reported by Guedes et al. (1995). It could be also seen that the effect of metaflumizone alone was merely equal to that mixture of methomyl+indoxacarb, whereas the general means of reduction percentages were 59.1 and 52.6, respectively). Therefore, the application of metaflumizone alone within IPM programs would be more useful than the use of the less effective mixture of methomyl+indoxacarb (Table 4).

During the second season of 2013 , the applied $1^{\text {st }}$ spray involved four insecticidal treatments as those of the $1^{\text {st }}$ spray of the $1^{\text {st }}$ season of 2012 evaluated against the tomato leafminer Tuta absoluta compared with the untreated check (Table 5). The results obtained ascertained again that the mixture of emamectin benzoate $+\mathrm{Kz}$ oil was the most effective treatment against the tomato leafminer, Tuta absoluta giving the highest general reduction of $48.4 .9 \%$, whereas emamectin benzoate alone recorded a lower general mean of reduction comprised $25.4 \%$. The treatment of Engeo ${ }^{\circledR}$ (a mixture of $14.1 \%$ thiamethoxam $+10.6 \%$ lambda-cyhalothrin) came in the second rank giving a general mean of reduction amounted to $35.8 \%$. Again, the addition of the mineral oil to emamectin benzoate has increased its residual effect and the efficacy of the applied mixture.

Moreover, the deduced mean number of inspected Tuta absoluta larvae and calculated reduction percentages due to the applications of different evaluated insecticidal after 5,7 and 10 days in the $2^{\text {nd }}$ spray are shown in Table 6 . In this concern, the calculated mean of general reduction is being used for evaluating the residual effect and to determine the efficacy of each of evaluated treatments. The results revealed that the applied mixture of chlorantraniliprole+ $\mathrm{Kz}$ mineral oil was the most potent treatment that reduced the number of Tuta absoluta larvae and gave a high general mean of reduction percentage of 94.2, followed by chlorantraniliprole (alone) (91.1\%) and chlorfenapyr + spinetoram (71.4\%). 
The treatment of using a trap+ detergent (as a spray) was the least efficient one, whereas the number of larvae were increased all over the adopted periods of inspection (Table 6); therefore the calculated general mean of reduction was as low as $4.6 \%$.

Table (2): Effect of certain tested insecticidal treatments against the tomato leafminer, Tuta absoluta infesting tomato plants in 2012 season ( $1^{\text {st }}$ spray)

\begin{tabular}{|c|c|c|c|c|c|c|c|c|c|c|}
\hline \multirow{4}{*}{ Treatments } & \multicolumn{10}{|c|}{$1^{\text {st }}$ season $(2012)$} \\
\hline & \multirow{3}{*}{$\begin{array}{c}\begin{array}{c}\text { Pre- } \\
\text { spray }\end{array} \\
\mathrm{A}^{* *}\end{array}$} & \multicolumn{6}{|c|}{$\begin{array}{c}\text { Average No. of larvae/8 plants }(\mathrm{A}) \text { and } \\
\% \text { infestation reduction (R) after } 11^{\text {st }} \text { spray at } \\
\text { different intervals (days) }\end{array}$} & \multirow{3}{*}{$\begin{array}{c}\text { L.S.D } \\
0.05\end{array}$} & \multicolumn{2}{|c|}{$\begin{array}{l}\text { General } \\
\text { Average }\end{array}$} \\
\hline & & \multicolumn{2}{|c|}{5} & \multicolumn{2}{|c|}{7} & \multicolumn{2}{|c|}{10} & & & \\
\hline & & A & $\mathrm{R}$ & $\mathrm{A}$ & $\mathrm{R}$ & $\mathrm{A}$ & $\mathrm{R}$ & & A & $\mathrm{R}(\%)$ \\
\hline Trap+Detergent & $16.0^{\mathrm{a} *}$ & $14.0^{\mathrm{b}}$ & 12.5 & $12.0^{\mathrm{c}}$ & 35.5 & $9.0^{\mathrm{d}}$ & 58.8 & 1.5 & 11.6 & 35.6 \\
\hline $\begin{array}{l}\text { Emamectin } \\
\text { benzoate }\end{array}$ & $19.0^{\mathrm{a}}$ & $17.0^{\mathrm{b}}$ & 10.5 & $18.0^{\mathrm{ab}}$ & 18.1 & $15.0^{\mathrm{c}}$ & 42.3 & 1.1 & 16.6 & 23.6 \\
\hline $\begin{array}{l}\text { Emamectin } \\
\text { benzoate + Kz oil }\end{array}$ & $19.0^{\mathrm{a}}$ & $16.0^{\mathrm{b}}$ & 15.7 & $12.0^{\mathrm{c}}$ & 45.4 & $10.0^{\mathrm{d}}$ & 61.5 & 1.4 & 12.6 & 40.9 \\
\hline Engeo $^{\circledR}$ & $19.0^{\mathrm{a}}$ & $17.0^{\mathrm{b}}$ & 10.5 & $17.0^{\mathrm{b}}$ & 22.7 & $12.0^{\mathrm{c}}$ & 53.8 & 1.2 & 15.3 & 29.0 \\
\hline Untreated check & $19.0^{\mathrm{c}}$ & $19.0^{\mathrm{c}}$ & - & $22.0^{\mathrm{b}}$ & - & $26.0^{\mathrm{a}}$ & - & 1.0 & 22.3 & - \\
\hline
\end{tabular}

${ }^{*}$ Means followed with the same letter(s) within the same row are not significantly different at 0.05 probability level.

$* * \mathrm{~A}=$ Average number of larvae and $\mathrm{R}=$ Infestation reduction percentage

Table (3): Effect of the evaluated insecticidal treatments against the tomato leafminer, Tuta absoluta infesting tomato plants in 2012 season $\left(2^{\text {nd }}\right.$ spray)

\begin{tabular}{|c|c|c|c|c|c|c|c|c|c|c|}
\hline \multirow{4}{*}{ Treatments } & \multicolumn{10}{|c|}{$1^{\text {st }}$ season $(2012)$} \\
\hline & \multirow{3}{*}{$\begin{array}{c}\begin{array}{c}\text { Pre- } \\
\text { spray }\end{array} \\
\text { A }\end{array}$} & \multicolumn{6}{|c|}{$\begin{array}{l}\text { Average No. of larvae/8 plants (A) and } \\
\% \text { infestation reduction (R) after } 2^{\text {nd }} \\
\text { spray at different intervals (days) }\end{array}$} & \multirow{3}{*}{$\begin{array}{l}\text { L.S.D } \\
0.05\end{array}$} & \multicolumn{2}{|c|}{$\begin{array}{l}\text { General } \\
\text { Average }\end{array}$} \\
\hline & & \multicolumn{2}{|c|}{5} & \multicolumn{2}{|c|}{7} & \multicolumn{2}{|c|}{10} & & & \\
\hline & & A & $\mathrm{R}$ & A & $\mathrm{R}$ & $\mathrm{A}$ & $\mathrm{R}$ & & A & $\mathrm{R}(\%)$ \\
\hline Trap+Detergent & $70.0^{\mathrm{d} *}$ & $80.0^{c}$ & $\begin{array}{c}-1.1 \\
\end{array}$ & $85.0^{\mathrm{b}}$ & -6.0 & $87.0^{\mathrm{a}}$ & -7.1 & 0.538 & 84.0 & -2.9 \\
\hline Chlorantraniliprole & $36.0^{\mathrm{a}}$ & $12.0^{\mathrm{b}}$ & 70.5 & $5.0^{\mathrm{c}}$ & 87.8 & $6.0^{\mathrm{c}}$ & 85.6 & 2.013 & 7.6 & 81.3 \\
\hline $\begin{array}{c}\text { Chlorantraniliprole } \\
\text { +Mineral oil }\end{array}$ & $32.0^{\mathrm{a}}$ & $8.0^{\mathrm{b}}$ & 77.8 & $3.0^{\mathrm{c}}$ & 91.8 & $0.1^{\mathrm{d}}$ & 100.0 & 2.599 & 3.7 & 89.9 \\
\hline $\begin{array}{c}\text { Chlorfenapyr + } \\
\text { Spinetoram }\end{array}$ & $43.0^{\mathrm{a}}$ & $20.0^{\mathrm{b}}$ & 58.8 & $6.0^{\mathrm{b}}$ & 87.8 & $6.0^{c}$ & 87.9 & 1.837 & 10.6 & 78.1 \\
\hline Untreated check & $69.0^{\mathrm{c}}$ & $78.0^{\mathrm{b}}$ & - & $79.0^{\mathrm{a}}$ & - & $80.0^{\mathrm{d}}$ & - & 1.591 & 79.0 & - \\
\hline
\end{tabular}

*Means followed with the same letter(s) within the same row are not significantly different at 0.05 probability level.

** $\mathrm{A}=$ Average number of larvae and $\mathrm{R}=$ Infestation reduction percentage. 
Table (4): Effect of the applied insecticidal treatments against the tomato leafminer, Tuta absoluta infesting tomato plants in 2012 season $\left(3^{\text {rd }}\right.$ spray $)$

\begin{tabular}{|c|c|c|c|c|c|c|c|c|c|c|}
\hline \multirow{4}{*}{ Treatments } & \multicolumn{10}{|c|}{$1^{\text {st }}$ season $(2012)$} \\
\hline & \multirow{3}{*}{$\begin{array}{c}\begin{array}{c}\text { Pre- } \\
\text { spray }\end{array} \\
\text { A }\end{array}$} & \multicolumn{6}{|c|}{$\begin{array}{c}\text { Average No. of larvae/8 plants }(\mathrm{A}) \text { and } \\
\% \text { infestation reduction }(\mathrm{R}) \text { after } 3^{\text {rd }} \text { spray at } \\
\text { different intervals (days) } \\
\end{array}$} & \multirow{3}{*}{$\begin{array}{c}\text { L.S.D } \\
0.05\end{array}$} & \multirow{2}{*}{\multicolumn{2}{|c|}{$\begin{array}{l}\text { General } \\
\text { Average }\end{array}$}} \\
\hline & & \multicolumn{2}{|c|}{5} & \multicolumn{2}{|c|}{7} & \multicolumn{2}{|c|}{10} & & & \\
\hline & & $\mathrm{A}$ & $\mathrm{R}$ & A & $\mathrm{R}$ & $\mathrm{A}$ & $\mathrm{R}$ & & $\mathrm{A}$ & $\mathrm{R}(\%)$ \\
\hline Trap+Detergent & $22.0^{\mathrm{b}}$ & $21.0^{\mathrm{c}}$ & 13.6 & $25.0^{\mathrm{a}}$ & -13.6 & $19.0^{\mathrm{d}}$ & -2.5 & 1.033 & 21.6 & -2.5 \\
\hline Metaflumizone & $8.0^{\mathrm{a}}$ & $5.0^{.0 \mathrm{~b}}$ & 43.4 & $4.0^{\mathrm{bc}}$ & 50.0 & $2.0^{\mathrm{c}}$ & 70.3 & 3.183 & 3.6 & 59.1 \\
\hline $\begin{array}{l}\text { Metaflumizone+ } \\
\text { Kz oil }\end{array}$ & 3.0 & 0.0 & 100 & 0.0 & 100.0 & 0.0 & 100.0 & ---- & 0.0 & 100.0 \\
\hline $\begin{array}{l}\text { Methomyl + } \\
\text { Indoxacarb }\end{array}$ & $8.0^{\mathrm{a}}$ & $4.0^{\mathrm{b}}$ & 54.7 & $3.0^{\mathrm{b}}$ & 62.5 & $4.0^{\mathrm{b}}$ & 40.6 & 2.599 & 3.6 & 52.6 \\
\hline Untreatedcheck & $19.0^{\mathrm{b}}$ & $21.0^{\mathrm{a}}$ & - & $19.0^{\mathrm{b}}$ & - & $16.0^{\mathrm{c}}$ & - & 1.125 & 18.6 & - \\
\hline
\end{tabular}

${ }^{*}$ Means followed with the same letter(s) within the same row are not significantly different at 0.05 probability level.

** $\mathrm{A}=$ Average number of larvae and $\mathrm{R}=$ Infestation reduction percentage.

Table (5): Effect of the performed insecticidal treatments against the tomato leafminer, Tuta absoluta infesting tomato plants in 2013 season ( $1^{\text {st }}$ spray)

\begin{tabular}{|c|c|c|c|c|c|c|c|c|c|c|}
\hline \multirow{4}{*}{ Treatments } & \multicolumn{10}{|c|}{$2^{\text {nd }} \operatorname{season}(2013)$} \\
\hline & \multirow{3}{*}{$\begin{array}{c}\begin{array}{c}\text { Pre- } \\
\text { spray }\end{array} \\
\text { A }\end{array}$} & \multicolumn{6}{|c|}{$\begin{array}{c}\text { Average No. of larvae/8 plants }(\mathrm{A}) \text { and } \\
\% \text { infestation reduction (R) after } 1 \text { st } \text { spray } \\
\text { at different intervals (days) }\end{array}$} & \multirow{3}{*}{$\begin{array}{c}\text { L.S.D } \\
0.05\end{array}$} & \multicolumn{2}{|c|}{$\begin{array}{l}\text { General } \\
\text { Average }\end{array}$} \\
\hline & & \multicolumn{2}{|c|}{5} & \multicolumn{2}{|c|}{7} & \multicolumn{2}{|c|}{10} & & & \\
\hline & & $\mathrm{A}$ & $\mathrm{R}$ & $\mathrm{A}$ & $\mathrm{R}$ & $\mathrm{A}$ & $\mathrm{R}$ & & $\mathrm{A}$ & $\mathrm{R}(\%)$ \\
\hline Trap+Detergent & $12.0^{\mathrm{a}}$ & $10.0 b^{c}$ & 16.6 & $11.0^{\mathrm{ab}}$ & 20.5 & $9.0^{\mathrm{c}}$ & 42.6 & 1.500 & 10.0 & 26.6 \\
\hline $\begin{array}{l}\text { Emamectin } \\
\text { benzoate }\end{array}$ & $13.0^{\mathrm{a}}$ & $12.0^{\mathrm{ab}}$ & 7.6 & $10.0^{\mathrm{c}}$ & 33.3 & $11.0^{\mathrm{bc}}$ & 35.2 & 1.423 & 11.0 & 25.4 \\
\hline $\begin{array}{l}\text { Emamectin } \\
\text { benzoate + Kz oil }\end{array}$ & $14.0^{\mathrm{a}}$ & $11.0^{\mathrm{b}}$ & 21.4 & $7.0^{\mathrm{c}}$ & 56.6 & $6.0^{\mathrm{c}}$ & 67.2 & 1.837 & 8.0 & 48.4 \\
\hline Engeo $^{\circledR}$ & $13.0^{\mathrm{a}}$ & $11.0^{\mathrm{b}}$ & 15.3 & $10.0^{\mathrm{b}}$ & 33.3 & $7.0^{\mathrm{c}}$ & 58.8 & 1.701 & 9.3 & 35.8 \\
\hline Untreated check & $13.0^{\mathrm{c}}$ & $13.0^{\mathrm{c}}$ & - & $15.0^{\mathrm{b}}$ & - & $17.0^{\mathrm{a}}$ & - & 1.248 & 15.0 & - \\
\hline
\end{tabular}

${ }^{*}$ Means followed with the same letter(s) within the same row are not significantly different at 0.05 probability level.

** $\mathrm{A}=$ Average number of larvae and $\mathrm{R}=$ Infestation reduction percentage.

The addition of the mineral oil (Kz oil) to chlorantraniliprole gave a highly effective mixture that reduced the incidence of Tuta absoluta larvae. In this concept, Bassi et al. (2012) reported that Chlorantraniliprole (Rynaxypyr ${ }^{\circledR}$, Coragen ${ }^{\circledR}$ and Altacor $\left.^{(}\right)$is a novel diamide insecticide by DuPont with 
outstanding performance on Tuta absoluta and has an extremely low mammalian toxicity profile. This compound was tested on $T$. absoluta since 2002 in Brasil at the DuPont R\&D Station in Paulinia; the early results indicated a new standard of $T$. absoluta control, even on insecticide-resistant populations.

The obtained results regarding the effect of the evaluated insecticidal treatments of carried out $3^{\text {rd }}$ spray during the season of 2013 against the tomato leafminer are presented in Table 7 . The treatment of metaflumizone+Kz oil was also the most effective treatment that rather reduced the infestation rate of Tuta absoluta after 10 daysof spraying and pronounced the highest general mean of reduction percentage of 74.4. Again, it is also noticed that metaflumizone (alone) was merely as effective as the mixture of methomyl+indoxacarb (a mixture of two carbamate insecticides) and therefore it is better to apply metaflumizone alone or with a mineral oil to increase the toxic efficacy of the applied compound against the insect-pest. Garzia et al. (2009) reported that the most effective insecticides for controlling Tuta absoluta in Sicily (Italy) are some chlorpyrifosand/or some pyrethrin products plus mineral oils.

As a conclusion, the addition of the mineral oil $\left(\mathrm{Kz}\right.$ oil $\left.{ }^{\circledR}\right)$ increased the efficiency of the evaluated insecticides :emamectin benzoate, chlorantraniliprole and metaflumizone; therefore it is recommended to admix mineral oil with each of thees effective evaluated insecticides. So, they could be used in IPM programs for achieving potent control of Tuta absoluta.

Table (6): Effect of the evaluated insecticidal treatments against the tomato leafminer, Tuta absoluta infesting tomato plants in 2013 season ( $2^{\text {nd }}$ spray)

\begin{tabular}{|c|c|c|c|c|c|c|c|c|c|c|}
\hline \multirow{4}{*}{ Treatments } & \multicolumn{10}{|c|}{$2^{\text {nd }} \operatorname{season}(2013)$} \\
\hline & \multirow{3}{*}{$\begin{array}{r}\begin{array}{c}\text { Pre- } \\
\text { spray }\end{array} \\
\mathrm{A}^{* *}\end{array}$} & \multicolumn{6}{|c|}{$\begin{array}{c}\text { Average No. of larvae/8 plants (A) and } \\
\% \text { infestation reduction (R) after } 2^{\text {nd }} \text { spray at } \\
\text { different intervals (days) }\end{array}$} & \multirow{3}{*}{ L.S.D 0.0 : } & \multicolumn{2}{|c|}{$\begin{array}{l}\text { General } \\
\text { Average }\end{array}$} \\
\hline & & \multicolumn{2}{|c|}{5} & \multicolumn{2}{|c|}{7} & \multicolumn{2}{|c|}{10} & & & \\
\hline & & A & $\mathrm{R}$ & A & $\mathrm{R}$ & $\mathrm{A}$ & $\mathrm{R}$ & & A & $\mathrm{R}(\%)$ \\
\hline Trap+Detergent & $26.0^{\mathrm{d}}$ & $27.0^{c}$ & 14.6 & $31.0^{\mathrm{b}}$ & 2.0 & $36.0^{\mathrm{a}}$ & -2.7 & 0.88 & 31.3 & 4.6 \\
\hline Chlorantraniliprole & $24.0^{\mathrm{a}}$ & $6.0^{\mathrm{b}}$ & 79.4 & $0.1^{\mathrm{c}}$ & 100.0 & $2.0^{\mathrm{c}}$ & 93.8 & 3.18 & 2.7 & 91.1 \\
\hline $\begin{array}{l}\text { Chlorantraniliprole } \\
\text { +Mineral oil }\end{array}$ & $19.0^{\mathrm{a}}$ & $4.0^{\mathrm{b}}$ & 82.7 & $0.1^{\mathrm{c}}$ & 100.0 & $0 \cdot 1^{\mathrm{c}}$ & 100.0 & 2.25 & 1.4 & 94.2 \\
\hline $\begin{array}{l}\text { Chlorfenapyr + } \\
\text { Spinetoram }\end{array}$ & $15.0^{\mathrm{a}}$ & $8.0^{\mathrm{b}}$ & 56.1 & $4.0^{\mathrm{c}}$ & 78.0 & $4.0^{\mathrm{c}}$ & 80.2 & 2.25 & 5.3 & 71.4 \\
\hline Untreated check & $23.0^{\mathrm{c}}$ & $28.0^{\mathrm{b}}$ & - & $28.0^{\mathrm{b}}$ & - & $31.0^{\mathrm{a}}$ & - & 0.90 & 29.0 & \\
\hline
\end{tabular}

*Means followed with the same letter(s) within the same row are not significantly different at 0.05 probability level.

** $\mathrm{A}=$ Average number of larvae and $\mathrm{R}=$ Infestation reduction percentage. 
Table (7): Effect of applied insecticdal treatments against the tomato leafminer, Tuta absoluta infesting tomato plants in 2013 season ( $3^{\text {rd }}$ spray)

\begin{tabular}{|c|c|c|c|c|c|c|c|c|c|c|}
\hline \multirow{4}{*}{ Treatments } & \multicolumn{10}{|c|}{$2^{\text {nd }} \operatorname{season}(2013)$} \\
\hline & \multirow{3}{*}{$\begin{array}{c}\begin{array}{c}\text { Pre- } \\
\text { spray }\end{array} \\
\mathrm{A}^{* *}\end{array}$} & \multicolumn{6}{|c|}{$\begin{array}{l}\text { Mean No. of larvae/8 plants (A) and } \\
\% \text { infestation reduction (R) after } 3^{\text {rd }} \text { spray } \\
\text { at different intervals (days) }\end{array}$} & \multirow{3}{*}{$\begin{array}{c}\text { L.S.D } \\
0.05\end{array}$} & \multirow{2}{*}{\multicolumn{2}{|c|}{$\begin{array}{c}\text { General mean } \\
(\%)\end{array}$}} \\
\hline & & \multicolumn{2}{|c|}{5} & \multicolumn{2}{|c|}{7} & \multicolumn{2}{|c|}{10} & & & \\
\hline & & A & $\mathrm{R}$ & $\mathrm{A}$ & $\mathrm{R}$ & A & $\mathrm{R}$ & & A & $\mathrm{R}$ \\
\hline Trap+Detergent & $15.0^{\mathrm{bc} *}$ & $17.0^{\mathrm{a}}$ & 7.2 & $16.0^{\mathrm{ab}}$ & -6.6 & $14.0^{\mathrm{c}}$ & 6.6 & 1.20 & 15.6 & 7.2 \\
\hline Metaflumizone & $6.0^{\mathrm{a}}$ & $4.0^{\mathrm{ab}}$ & 45.4 & $3.0^{\mathrm{b}}$ & 50.0 & $2.0^{\mathrm{b}}$ & 66.6 & 3.18 & 3.0 & 54.0 \\
\hline $\begin{array}{l}\text { Metaflumizone+ } \\
\text { Kz oil }\end{array}$ & $1.9^{\mathrm{a}}$ & $0.7^{\mathrm{a}}$ & 99.3 & $0.7^{\mathrm{a}}$ & 62.0 & $0.7^{\mathrm{a}}$ & 62.0 & 4.50 & 0.7 & 74.4 \\
\hline $\begin{array}{l}\text { Methomyl + } \\
\text { Indoxacarb }\end{array}$ & $6.0^{\mathrm{a}}$ & $3.0^{\mathrm{b}}$ & 59.0 & $2.0^{\mathrm{b}}$ & 66.6 & $3.0^{\mathrm{b}}$ & 50.0 & 3.18 & 2.6 & 58.5 \\
\hline Untreated check & $9.0^{\mathrm{b}}$ & $11.0^{\mathrm{a}}$ & - & $9.0^{b}$ & - & $9.0^{b}$ & - & 1.50 & 9.6 & - \\
\hline
\end{tabular}

${ }^{*}$ Means followed with the same letter(s) within the same row are not significantly different.

\section{REFERENCES}

Baniameri, V. and A. Cheraghian (2012). The first report and control strategies of Tuta absoluta in Iran. OEPP/EPPO Bulletin, 42(2):322324.

Bassi, A., J. L. Rison, E. Roditakis and L. Sannino (2012). Chlorantraniliprole (Rynaxypyr $^{\circledR}$, Coragen $^{\circledR}$, Altacor ${ }^{\circledR}$ ) key features for sustainable control of Tuta absoluta. IOBC/WPRS Bulletin, 80:193-198.

Bue, P. L, S. Abbas, E. Peri and S. Colazza (2012). Use of biorational insecticides for the control of Tuta absoluta (Meyrick) infestations on open field tomato. New Medit, 11(4 [Special issue]):39-41.

Bueno, V. H. P., F. C. Montes, A. M. C. Pereira, J. C. Lins and J. C. vanLenteren (2012). Can recently found Brazilian hemipteran predatory bugs control Tuta absoluta?. IOBC/WPRS Bulletin, 80:63-67.

COSTAT Software (1988). Microcomputer Program Analysis. Co-Hort software, Berkely, CA, USA.

Derbalah, A. S., S. Z. Morsey and M. El-Samahy (2012). Some recent approaches to control Tuta absoluta in tomato under greenhouse conditions. Afr. Entomol., 20:27-34.

Desneux, N., E. Wajnberg, K. A. G. Wyckhuys, G. Burgio, S. Arpaia, C. A. Narvez-Vasquez, J. Gonzalez, D. Ruescas, E. Tabone, J. Pizzol, C. Poncet, T. Cabello and A. Urbaneja (2010). Biological invasion of European tomato crops by Tuta absoluta: ecology, geographic expansion and prospects for biological control. J. Pest. Sci., 83:197215.

FERA (2009). South American tomato moth Tuta dbsoluta. Food and Environment Research Agency, Department for Environment Rood and Rural Affairs. 
Garzia, G. T., G. Siscaro, A. Colombo and G. Campo (2009). Reappearance of Tuta dbsoluta in Sicily [Rinvenuta in Sicilia Tuta absoluta]. L'Informatore Agrario, 65: 71-71.

Guedes, R. N. C., M. C.Picanco, A. L. Matioli and D. M.Rocha (1994). Efeito de inseticidas e sistemas de conduc o do tomateiro no controle de Scrobipalpuloides absoluta (Lepidoptera: Gelechiidae). An. Sot. Entomol. Brasi., 123: 321-325.

Guedes, R. N. C., M. C. Picanco, N. M. P. Guedes and N. R. Madeira (1995). Sinergismo do 6 mineral sobre a toxicidade de inseticidas para Scrobipalpuloides absoluta (Lepidoptera: Gelechiidae). Pesq. Agropec. Bras., 30: 313-318.

Hanafy, H. E. M. and W. El-Sayed (2013). Efficacy of bio-and chemical insecticides in the control of Tuta absoluta (Meyrick) and Helicoverpa armigera (Hubner) infesting tomato plants. Aust. J. Basic Appl., 7: 943.

Henderson, C. F. and E. W.Tilton (1955). Tests with acaricides against the brown wheat mite. J. Econ. Entomol., 48: 157-161.

Hrnčic', S. and S. Radonjic (2011). Tuta absoluta Meyrick (Lepidoptera, Gelechiidae), a new pest in Montenegro. IOBC/WPRS Bull., 68: 71-74.

IRAC (2007). Tomato leafworm resistance management practice in Brazil. IRAC (Insecticide Resistance Action Comittee) News-Resistance Management News, Conferences and Symposia, 15: 3.

IRAC (2009a). Tuta absoluta on the move. IRAC (Insecticide Resistance Action Committee) Newsletter. Connection (20).

IRAC (2009b). Lepidoptera Insecticide Mode of Action Classification Poster. IRAC (Insecticide Resistance Action Committee).

Izhevsky, S. S., A. K. Akhatov and S. Yu. Sinyov (2011). Tuta absoluta has been detected in Russia. Zashchita Karantin Rastenii, (3):40-44. [Russian]

KIc, T. (2010). First record of Tuta absoluta in Turkey. Phytoparasitica, 38(3):243-244.

Lietti, M. M. M., E. Botto and R. A. Alzogaray (2005). Insecticide resistance in Argentine populations of Tuta absoluta (Meyrick) (Lepidoptera: Gelechiidae). Neotrop. Entomol. 34:113-119.

Mallia, D. (2009). Guidelines for the control and eradication of Tuta absoluta. Ministry for Resources and Rural Affairs, Plant Health Department, Malta.

Miniermotte, E. (2010). Tuta absoluta on the way from the South. Gemuse (Munchen), 46(2):25-27. [German]

Mohamed, E. S. I., M. E. Mohamed and S. A. Gamiel (2012). First record of the tomato leafminer, Tuta absoluta (Meyrick) (Lepidoptera: Gelechiidae) in Sudan. OEPP/EPPO Bulletin, 42(2):325-327.

Mohammed, A. S. (2010). New record for leafminer, Tuta absoluta (Lepidoptera: Gelechiidae) infested tomato plantations in Kafr El-Sheikh region. J. Agric. Res. Kafer El-Sheikh Univ., 36:238-239.

Picanco, M. C., R. N. Guedes, G. L. D Leite, P. C. R. Fontes and E. A. Silva (1995). IncidCncia de Scrobipalpuloides absoluta em tomateiro sob diferentes sistemas de tutoramento e de controle qufmico. Hortic. Bras., 13:180-183. 
Ramadan, G. R. M. (2014). Efficiency and residue analysis of certain insecticides for control of tomato leafminer, Tuta absoluta. M. Sc. Thesis, Faculty of Agric. Alex. Univ., Egypt.

Riquelme, M. B., E. N. Botto and C. Lafaice (2006). Efficacy of insecticides against the tomato moth, Tuta absoluta (Lepidoptera:Gelcchiidae) and their residual effects on the parasitoid Trichogrammatoidea bactrae (Hymenoptera: Trichogrammatidae) Rev. Soc. Entomol. Argent., 65: 5765.

Roditakis, E., D. Papachristos and N. E. Roditakis (2010). Current status of the tomato leafminer Tuta absoluta in Greece. OEPP/EPPO Bulletin, 40(1):163-166.

Russell (2009) . Tuta absoluta- Insect Profile. Russell IPM Ltd.

Salazar, E. R. and J. E. Araya (2001). Response of tomato leaf moth Tuta absoluta (Meyrick) to insecticides in Africa). Agricultura Tecnica, 61:429-435.

Seplyarsky, V., M. Weiss and A. Haberman (2010). Tuta absoluta povolny (Lepidoptera: Gelechiidae), a new invasive species in Israel. Phytoparasitica, 38(5):445-446.

Shalaby, E. M., M. M. Soliman and E. M. Abd El-Mageed (2012). Evaluation of some insecticides against tomato leaf minor (Tuta absoluta) and determination of their residues in tomato fruits. Appl. Biol. Res., 14:113119.

Siqueira, H. A. A., R. N. C. Guedes and M. C. Picanco (2000a). Insecticide resistance in populations of Tuta absoluta (Lepidoptera: Gelechiidae). Agric. Forest Entomol., 2:147-153.

Siqueira, H. A. A., R. N. C. Guedes and M. C. Picanco (2000b). Cartap resistance and synergism in populations of Tuta absoluta (Lep., Gelechiidae). J. Appl. Entomol., 124: 233-238.

Soliman, M. M. M., A. S. H. Abdel-Moniem and M. A. Abdel-Raheem (2013). Impact of some insecticides and their mixtures on the population of tomato borers, Tuta absoluta (Meyrick) (Lepidoptera: Gelechiidae) and Helicoverpa armigera (Hiibner) (Lepidoptera: Noctuidae) in tomato crop at Upper Egypt. Arch. Phytopathol. Plant Protect., 47: 1764-1776.

Steel, R. G. D. and J. H. Torrie (1981). Principles and procedures of statistic. A biometrical approach. $2^{\text {nd }}$ Ed. McGraw. Hill Kogahusha Ltd. PP. 633.

Unlu, L. (2012). Potato: a new host plant of Tuta absoluta Povolny (Lepidoptera: Gelechiidae) in Turkey. Pakistan J. Zool., 44(4):11831184. 


\section{المــــص الـعـريسي}

\section{المكافحة المتكاملة للتوتا أبسليوتا التي تصيب نباتات الطماطم في مصر}

عبدالقتاح سيد عبدالكريم سعد1 ، السيد حسن محمد تايب1 ، ليلي محمد عبدالتبي2 هـي جابر عطية2

1- قسم وقاية النبات- كلية الزراعة (سابا باشا)- - الإسكندرية - مصر

2- مركز البحوث الزراعية - الصبحية - الإسكندرية - مصر بلتئه

\section{نم رش نباتات الطماطم 3 رشات نم فيها نقييم معاملات كيميائية مختلفة خلال موسمي 2012 و 2013} لمكافحة نافقة أوراق الطماطم التوتا أبسيليوتا في فترات بينية (15 يوم بين الرشة والأخري). أوضحت النتائج خلال الموسم الأول أن المعاملة المكونة من مبيد إيمامكنين بنزوات وزيت Kz أظهرت كفاءة عالية في خفض الإصابة والتي وصلت إلي 40,9 \% بالمقارنة بالمعاملات الأخري في الرشة الأولي. كما أظهرت النتائج أن أن المعاملة المكونة من خليط الزيت المعدني ومركب كلورانترانيلييرول كانت أكفأ المعاملات المختبرة وسجلت أعلي منوسط عام لخفض الإصابة الذي نم حسابه خلال عشرة أيام من الفحص حيث بلغ هذا الخفض 81,3\% بعد الرشة الثانية. أما بعد الرشة الثالثة والتي أُستعمل فيها خليط الزيت المعدني مع مبيد ميتافلوميزون أظهر هذا الخليط أيضاً كفاءة عالية محققاً الخفض الكامل لأعداد الحشرة في النباتات المعاملة وذلك بعد الرشة الثالثة .

كما أوضحت النتائج المتحصل عليها في الموسم الثاني (2013) تأكيد نفس الإتجاه في النتائج المتحصل عليها في الموسم الأول حيث أظهرت النتائج أيضاً أن إضافة الزيت المعدني Kz أدي إلي زيادة كفاءة المبيدات المختبرة والتي تم خلطها معه (إيمامكتين بنزوات ، كلورانترانيليبرول ، ميتافلوميزون) ولهذا يمكن إضافة الزيت المعدني للمبيدات الفعالة والمستخدمة ضمن برامج المكافحة المتكاملة لحشرة التونا أبسيليونا. 